\title{
QUALITY CULTURE, ETHICAL CLIMATE, PERSON-ORGANIZATION FIT AND ORGANIZATIONAL COMMITMENT: AN EMPIRICAL INVESTIGATION
}

\author{
Hakan KITAPÇI
}

Meral ELÇI

\author{
Gebze Institute of Technology
}

\begin{abstract}
In this study, the existence of a relationship among the Quality Culture, Ethical Climate of an organization, Organizational Commitment and PersonOrganization Fit is investigated using the data collected from manufacturing firms which are operating in automotive sector in Gebze region. Hypothesized relationships are tested through a survey study of 253 employees in these firms which are currently applying $T Q M$ practices. A hypothetical relationships tested by regression analysis. The coefficients obtained from the regression model supported the proposed model. The findings revealed that Quality Culture and PersonOrganization Fit were found to be significantly related to Organizational Commitment. Also, Quality Culture and Ethical Climate were found to be significantly related to Person-Organization Fit.
\end{abstract}

Keywords: Quality Culture, Ethical Climate, PersonOrganization Fit and Organizational Commitment.

\section{INTRODUCTION}

Many companies undertaking TQM programmes have, in recent times, switched their attention from applying the tools and techniques of TQM to attempting to align their TQM programme with their prevailing organizational culture (Maull et al., 2001). Advocates of organizational excellence eschew the problems associated with achieving a flexible, adaptable and committed workforce in organizations (Reeves and Bednar, 1994). This is because they lack a dominant and coherent culture, in which values, commitments and approaches are likely to diverge, which can present a barrier to co-operation, joint action and problem solving across the organization. Thus, managers should periodically analyze the relevance of corporate values to the evolving organizational environment. As a result, enabling managers to adapt and nurture the constructs that support the development of an aspired organizational culture.
There has been a push to understand the nature of organizations through the concept of climate. Research has demonstrated that climate is a significant factor that influences both productivity and satisfaction among its members. The factors that influence the perception of ethical behavior in an organization would be extremely important for the leadership or managers of any group of people in order to foster ethical conduct as opposed to unethical conduct (Malloy and Agarwal, 2003).

Climate refers to the ways organizations operationalize routine behaviors and the actions that are expected, supported and rewarded (Schneider and Rentsch 1988). A firm's Ethical Climate dictates its ethical values and the behaviors expected. Victor and Cullen define Ethical Climate as, "the prevailing perceptions of typical organizational practices and procedures that have ethical content $(1988 ; 101)$." A firm's Ethical Climate may be viewed as a composite of organizational members' perceptions of the ethical values and behaviors supported and practiced by organizational members. When a climate is created in which ethical values and behaviors are fostered and supported, more ethical behavior is expected to exist (Upchurch and Ruhland, 1996; Wimbush and Shepard, 1994).

Creating an Ethical Climate via ethical codes, ethical policies, and rewards/punishments should reduce the chance of unethical choices as defined by the organization (Schwepker, et.al., 1997).

Many researches about person-organization fit have shown essential implications for organizational outcomes and also individual well-being. For example, the fit between a person's values and organizational values is associated with behavioral and affective outcomes, such as greater organizational commitment, better job performance and longer tenure (O'Reilly et. al., 1991; Vianen, 2000).

We examine empirically the relationship among 
Quality Culture, Ethical Climate, Organizational Commitment and Person-Organization Fit. We hope, the results of our study may provide useful insights for more effective management. We begin by describing the theoretical foundation for this research problem. Next, we discuss research methods and results. We interpret our findings, assess contributions to theory, and discuss.

\section{THEORETICAL FRAMEWORK Quality Culture and Organizational Commitment}

Total quality management, is another different dimension of the culture movement. Organizational culture and total quality management has combined together in order to reach perfection and quality. To work with the organizational culture or to change the organizational culture is inevitable (Lewis, 1996). For the total quality management to be implemented common values, sample models and organizational understanding should be changed. These changes will affect the basic believes and values of the workers concerning their work (Ngowi, 2000). Therefore organizations define their organizational cultures before implementing their TQM (TKY) programmes (Maull et al., 2001). Organizational culture affects the activities and behaviors of the workers. It also changes their expectations regarding their works (Reeves and Bednar, 1994). Focusing on quality is a change towards making radical arrangements in the inherent culture of the business (Sandholm, 1999).

Total quality management is a philosophy which the organization can use for the betterment of the organization's own performance. Technique and tools it harbors inside serve as basis. Thus it can become a precedent to a culture to be formed and is open to change (Page and Curry, 2000). Lakhe and Mohanty (1994), lists the criteria necessary to improve the Quality Culture as such;

$\checkmark$ Process, procedure and policy of the organization should emphasize the quality certainly.

$\checkmark$ Anybody working in the organization should understand the importance of the quality in fulfill ing the aims of the business.

$\checkmark$ Workers at all levels should for sure be aware of the requirements and needs of the customer.

$\checkmark$ Business infrastructure should permit the continual betterment attempts.

$\checkmark$ Internal and external customer requirements should be integrated into quality plan of the business.

$\checkmark$ Using performance criteria based on customer is important.

$\checkmark$ A tight communication network should be devel oped.

$\checkmark$ Customer loyalty should be developed.

$\checkmark$ Values and believes concerning customer should be emphasized and assisted by top management.

Implementation of total quality is not easy. It is necessary that the culture of the organization be changed, the responsibility assumed by the management of the business and the integration in the process of betterment of the culture (Lakhe and Mohanty, 1994).

Taking into consideration above mentioned information, we predict that Quality Culture affects PersonOrganization Fit and Organizational Commitment.

H1: Quality Culture is positively related to PersonOrganization Fit

H4: Quality Culture is positively related to Organizational Commitment

\section{Ethical Climate and Organizational Commitment}

Although Organizational Commitment continues to interest researchers because of its positive effects on organizations, we know relatively little about the effects of the ethical context on Organizational Commitment. As such, we contribute to the Organizational Commitment field by assessing the effects of Ethical Climates on Organizational Commitment.

About Organizational Commitment inquiries remain popular. This maintains effort to study Organizational Commitment. There are important relationships with Organizational Commitment and a number of organizational phenomena such as absenteeism and tardiness (Bateman and Strasser, 1984), organizational citizenship behaviors (Williams and Anderson, 1991), and, in some cases, performance and productivity (Morris and Sherman, 1981). However, although the plenty of research on Organizational Commitment, we know relatively little about the effects of Ethical Climate on Organizational Commitment.

Organizational Commitment as the relative strength of an individual's identification and involvement in a particular organization (Steers, 1977). According to Porter et al. (1974) Organizational Commitment can be characterized by: (1) a strong belief and acceptance of the organization's goals and values, (2) willingness to exert considerable effort for the organization, and (3) a strong desire to remain a member of the organization. 
The researches done recently have shown that organizational climates are related with Organizational Commitment of those who work (Randi, 1998; 386-392; Zehir, Elçi and Savi, 2003; Valentine et.al., 2002).

Similarly, a research done with marketing managers found a positive relation between Organizational Commitment and the dimension of the Ethical Climate regarding to its dimension. Finally, a research done with a group of hospital workers most of whom are women have shown that the workers are more committed to their organizations when the Ethical Climate they have chosen and the ethical work climates they work in match (Schwepker, 2001; 41-42).

Similar to recent studies with professionalized workers (e.g., Schwepker, 2001), Cullen and Victor (2003) found a positive relationship between Organizational Commitment and individual perceptions of principled Ethical Climates for the study. Their results showed that benevolent climates are positively related to Organizational Commitment while egoistic climates are negatively related to commitment. They also found a positive relationship of Organizational Commitment with a principled climate.

Cullen and Victor (2003)'s findings consistent with the research (Trevino et al., 1998; Wimbush and Shepard, 1994) perceptions of egoistic climates were negatively related to Organizational Commitment. If individuals perceive an egoistic or self-interested climate, they believe they are encouraged by the organization to promote their own self-interest and probably also view other employees as self-interested (Cullen and Victor, 2003; 138). Research in this area leads to the following hypothesis:

H3: Ethical Climate is positively related to Organizational Commitment

\section{Organizational Commitment and Person-Organization Fit}

Chatman (1989) defines Person-Organization Fit "as the congruence between the norms and values of organizations and the values of persons" (p. 339). The emphasis here is on the congruity between personal and organization beliefs or individual and company goals. The degree of fit can also depend on how well a firm supports employee needs or on how appropriately the personality of an individual fits the company context "(Kristof, 1996; 4).

Person-organization (P-O) fit, or the compatibility between people and the organizations in which they work, is a key to maintaining a flexible and committed workforce that is necessary in a competitive business environment (Cable and Parsons, 2001; 1). Several attempts to study Person-Organization Fit have been undertaken by a number of research studies (Valentine et al., 2002; Vancouver et.al., 1994; Vancouver and Schmitt, 1991, Dawes, 1988; Rothstein and Jackson, 1980; Sims and Kroeck, 1994; Snyder et al., 1988). Poor person-organization match has been shown to result in greater of turnover (Chatman, 1991; O'Reilly et. al., 1991; Vancouver et.al., 1994; Vancouver and Schmitt, 1991) and poor job performance (Bretz and Judge, 1994; Downey et. al., 1975; Pritchard and Karasick, 1973; Tziner, 1987).

Organizational Commitment may also enhance individual's perceptions of $\mathrm{P}-\mathrm{O}$ fit. Because Organizational Commitment is related to the degree to which employees take ownership of company values and prefer to help the firm (Mowday et. al., 1979), which would likely increase the perceived congruence between individual and company characteristics (Valentine et. al., 2002).

Research has shown that congruence between individual values and corporate values correlates significantly with such job outcomes as individual productivity, job satisfaction, and commitment (O'Reilly et al., 1991). Some other researchers have also showed Organizational Commitment was positively related to Person-Organization Fit (Meglino et al., 1989; Chatman, 1991; Vancouver and Schmitt 1991; Ostroff, 1993; Valentine, et. al., 2002; Saks and Ashforth, 1997). Therefore, we hypothesis that:

H5: Employees' perceptions of P-O fit will have a positive impact on Organizational Commitment

\section{Ethical Climate and Person-Organization Fit}

Sims and Keon, (1997) purposed determine if there is a relationship between the Ethical Climate of the organization and the development of PersonOrganization Fit. Results indicate that a match between individual preferences and present position proved most satisfying. Subjects expressing a match between their preferences for an ethical work climate and their present ethical work climate indicated that they were less likely to leave their positions. Another result of the researches, (1997) study provides partial support for the assumption that individuals and organizations with similar ethics and values provide satisfying environments. Finally, Sims and Keon's, (1997) paper indicated that as employees find themselves in work climates that are similar to their preferences, 


\section{Figure 1: $\wedge$ path muxlel of the study}

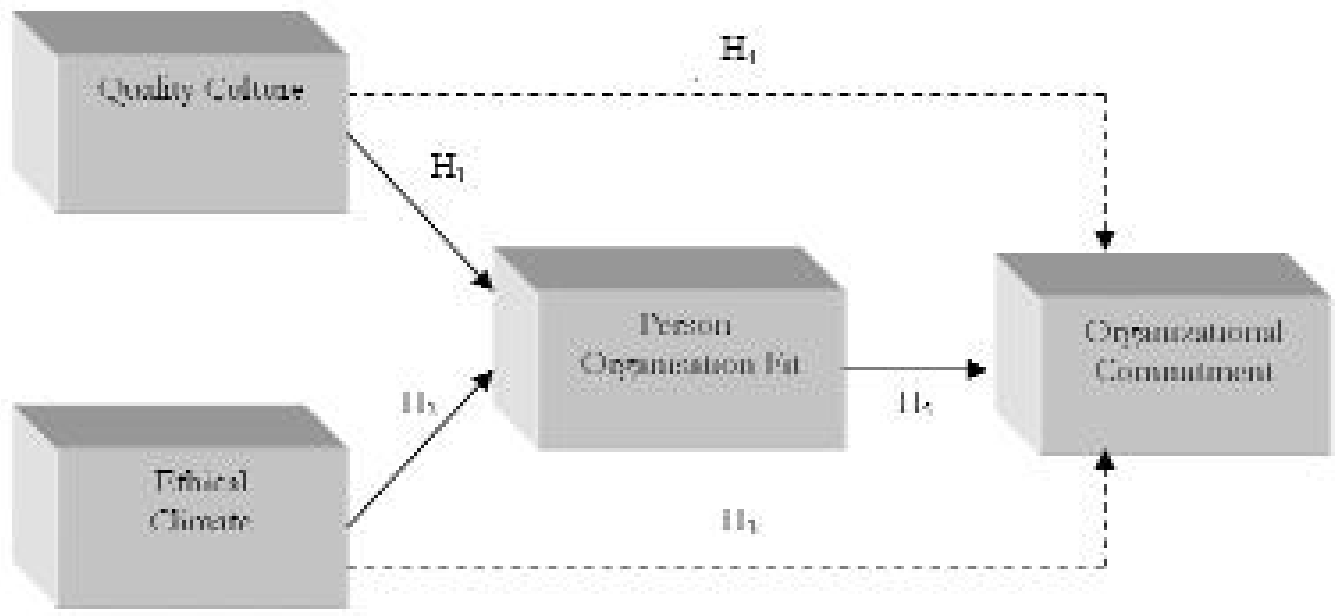

they tend to be more satisfied and less likely to leave. The development of an ethical context might enhance Person-Organization Fit because employees often prefer moral company values (Vidaver-Cohen, 1998; Jose and Thibodeaux, 1999). Valentine et. al. (2002), also find that corporate ethical values were positively associated with Person-Organization Fit. The evidence suggests that Ethical Climate may be related to Person-Organization Fit as follows:

\section{H2: Ethical Climate is positively related to Person- Organization Fit}

The purpose of this study is to interrogate many proposed relationships that are not fully explored in the ethics literature. Our model (Figure 1) emphasizes associations among Ethical Climate, Organizational Commitment and Person-Organization Fit will be tested. This study is important because if managers develop strong Ethical Climates in their organizations, they can set a strong link up between the workers and their organizations.

\section{METHOD \\ Procedure and Sample}

The data was collected via questionnaire from employees who work in manufacturing firms which are operating in automotive sector in Gebze region. A total of 253 responses were collected from employees of ten automotive organizations which had adopted TQM programs.

\section{Measures}

The Ethical Climate (EC) measure, previously used by
Schwepker, Ferrell and Ingram (1997), consisted of seven items which measure the presence and enforcement of codes of ethics, corporate policies on ethics, and top management actions related to ethics. Higher average scores reflect employees' perception of a more Ethical Climate. Person-Organization Fit assessed with a 4-item scale developed by Netemeyer et.al. (1997). Organizational Commitment, on the other hand, was measured with the 4-item scale which is developed by Ackfeldt and Coote (2003), Babin and Boles (1998), Hartline and Ferrell (1996), Netemeyer et. al. (1997). Quality Culture was measured with the 10-item scale which is developed by Ahire et al. (1996). All items were measured on a five point Likert-type scale where $1=$ strongly disagree and $5=$ strongly agree.

\section{Sample Characteristics}

The sample characteristics are as the following: Around $72,7 \%$ of the sample are males and $66 \%$ of them are married. The mean of the age is 33. Around $45 \%$ of the smple have university graduate degree and $33,5 \%$ of them have high school degree. The $39,8 \%$ of the respondents are office staff and 36,5\% of them are middle level managers.

\section{Data Reduction}

Table 1 shows the results of a principal component factor analysis including a varimax rotation for each of 22 questionnaire items included in this analysis. Four of these items in the study were Organizational Commitment indicators, four were Ethical Climate indicators, four were Person-Organization Fit indicators and ten were Quality Culture indicators. The four factors captured all of the variance with $26 \%, 19 \%$, 
Table I: Results of a Principal Component l'actor Analysis

\begin{tabular}{|c|c|c|c|c|}
\hline ITEMs & 忢至 & 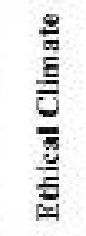 & 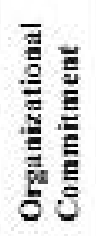 & $\begin{array}{l}\vec{E} \\
0 \\
\vdots\end{array}$ \\
\hline All cmployes suggestions are evolunted & $79 \mathrm{~K}$ & & & \\
\hline SPC is used exiensively in our plisnt & .797 & & & \\
\hline Fimplayes are encouragal to give suggestions & .769 & & & \\
\hline $\begin{array}{l}\text { To achieve grester custonicr salisfaction, our company actively secks ways to } \\
\text { innorwe our primary product }\end{array}$ &, 766 & & & \\
\hline $\begin{array}{l}\text { Line wurkers have lechnical assistance available to them to belp them solve } \\
\text { quality problems }\end{array}$ &, 740 & & & \\
\hline Quality inlormation is displiayct as rnust of the work stations & .739 & & & \\
\hline $\begin{array}{l}\text { There are almost ulways some kinds of employce quaslity training going on in } \\
\text { our plini. }\end{array}$ & 642 & & & \\
\hline Our company has heeri custunner focused & .686 & & & \\
\hline Line workers are encouragod to fix problems they find &, 648 & & & \\
\hline We have elcar quality goals ideatified by top-level munugers & ,6:3) & & & \\
\hline $\begin{array}{l}\text { Al cunprealy wide moetings top-level managers often discuss the importance of } \\
\text { quality }\end{array}$ & .623 & & & \\
\hline My company strictly enforces policies regarving ethical behavior. & & .836 & & \\
\hline My company bas policies with repirds ts ethical hehavior. & & .830 & & \\
\hline My compuny has a lormall, wrillen cade of cthics. & & .814 & & \\
\hline My compriary strictly enfunces a code of cthics. & & 800 & & \\
\hline 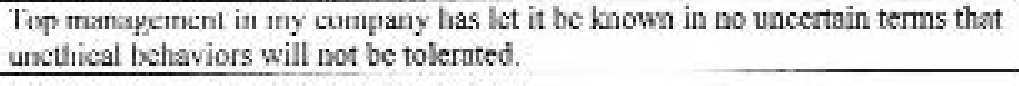 & & .699 & & \\
\hline I fecl a strong sense of belonging to this compuny. & & & .836 & \\
\hline This company has a great deal of personal meaniny firr mic. & & & .786 & \\
\hline I foel like purt of the fiamily at this corropany. & & & .757 & \\
\hline 1 feel emotionally illis:hed to this company. & & & .729 & \\
\hline This organization fias the sante values as i do with regard to concem for others. & & & &, 7736 \\
\hline This orpranizalion has the sarne values as i do with regard to fairness. & & & &, 689 \\
\hline This organization flas the sance values as i do with regard to honesty. & & & & .650 \\
\hline 1 feel thut my pervonal values are a gond lit with this organization. & & & & 588 \\
\hline
\end{tabular}

$14 \%$, and $10 \%$ of the variance respectively. Items can be dropped if factor loadings are less than. 400. The lowest loading in this study was .639 , factor loadings above. 40 can be retained in exploratory studies (Hair, Anderson and Tatham, 1987), so all items were retained in the analysis.

\section{Descriptives, Correlations and Alpha Reliabilities of the Measures}

Displayed in Table 2 are the correlations across Quality Culture, Ethical Climate, P-O Fit and
Organizational Commitment. As shown in the Table, all variables are significantly and positively correlated with each other.

Table 2: Descriptives, Correlations and Alpha Reliabilities of the Measures

\begin{tabular}{|l|l|l|l|l|l|l|}
\hline & MEAN & SD & OC & EC & POF & QC \\
\hline OC & 3,59 &, 95 & $\mathbf{8 7 a}$ &, $473 * *$ &, $597 * *$ &, $535 * *$ \\
\hline EC & 3,69 &, 85 & &, $91 a$ &, $694 * *$ &, $525 * *$ \\
\hline POF & 3,15 & 1,02 & & & $\mathbf{9 0 a}$ &, $514 * *$ \\
\hline QC & 3,65 &, 82 & & & &, $93 a$ \\
\hline
\end{tabular}

** Correlation is significant at the 0.01 level (2-tailed). a Chronbach alfa 
Chronbach ? statistics were computed with values of. $87, .91, .90, .93$ for each of the four factors, respectively. For exploratory research, Chronbach ? greater than. 70 is generally considered reliable (Nunnally, 1967).

\section{Regression Analysis}

Having identified four factors for these organizations, a primary purpose of this study was to observe the relationship between these factors. As shown in Table 1 , the factors described in section data reduction were utilized as independent variables to determine their usefulness for predicting changes in the dependent variables. For each of the factors, a factor variable was created by averaging the responses for this items contained within the factors $(n=253)$. These hypothetical relationships are shown in Fig.1. Regression was used to explore these relationships.

Table 3 shows the result of regression analysis, relating these three factors to Organizational Commitment. This table shows only the statistically significant models. As shown in Table 3, all of the regressions were highly significant $(\mathrm{p}<.01)$.

Table 4 shows the result of regression analysis, relating two factors to Person-Organization Fit. This table shows only the statistically significant models. As shown in Table 4, all of the regressions were highly significant $(\mathrm{p}<.01)$.
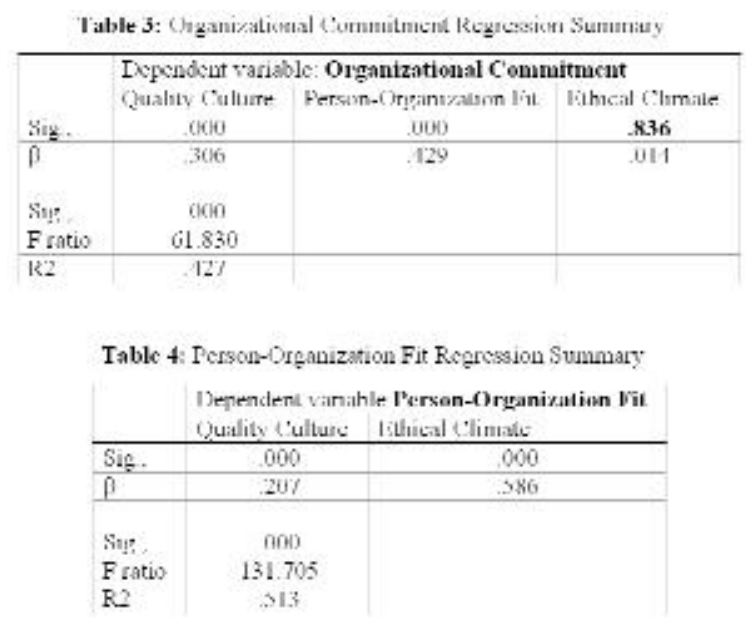

In Table 3; Factor 1 was significantly related to Organizational Commitment. Factor 3 was not related to Organizational Commitment. This implies that Ethical Climate does not affect Organizational Commitment. Factor 4 was significantly related to Organizational Commitment. This implies that person- organization fit affects Organizational Commitment. In Table 4; Factor 1 and 3, are significantly related to Person-Organization Fit.

\section{Discussion and Implications}

The factors that we created in this study were found to be related to Organizational Commitment within the plants in these firms. As is shown in Table 3, PersonOrganization Fit and Quality Culture were found to be significantly related to Organizational Commitment. On the other hand Ethical Climate was not found related to Organizational Commitment. We also found that Quality Culture and Ethical Climate were found to be significantly related to Person-Organization Fit.

On the other hand, according to our findings, PersonOrganization Fit fully mediates the relationship between Ethical Climate and Organizational Commitment. This mediation suggests that Ethical Climate increases Person-Organization Fit through its positive effects on Organizational Commitment.

Quality Culture impacts the employees' activities and behaviors. By means of this impact, employees will have similar basic believes and values concerning their work with the other person and the organization. This case, will supply to spread Quality Culture in organization and also it will obtain to facilitate employees' adaptation to organization and to increase the employee's commitment to their organizations. Ethical Climate supplies employees both to adapt and to feel dependence to their organizations. If an organization's Ethical Climate similar with the employees' values, the employee can easily adapt to their organization.

Consequently, if managers want to increase to employee's Organizational Commitment, they should diffuse the Quality Culture and should strengthen Ethical Climate in their organizations. 


\section{REFERENCES}

Ackfeldt, A.L.; Coote, L.V., (2003), A Study of Organizational Citizenship Behaviors In a Retail Setting, Journal of Business Ethics, Article In Pres.

Ahire, S. S., Golhar, D. Y., and Waller, M. A., (1996), Development and Validation of TQM Implementation Contructs, Decision Sciences, Vol: 27, No: 1, Winter, pp.23-56

Babin, B.J. and Boles, J.S. (1998), Employee Behavior in a Service Environment: a Model and Test of Potential Differences between Man and Women. Journal of Marketing, 62, pp.77-91.

Bateman, S.T. and. Strasser, S: (1984), A Longitudinal Analysis of The Antecedents of Organizational Commitment, Academy of Management Journal 27, pp.95-112.

Bretz, R., and Judge, T. (1994). Person-Organization Fit and The Theory of Work Adjustment: Implications For Satisfaction, Tenure, and Career Success. Journal of Vocational Behavior 44, pp.32-54.

Cable, D.M. and Parsons, C.K., (2001), Socialization Tactics and Person-Organization Fit, Personnel Psychology, Spring, 54,

Caldwell, D.F and O'Reilly, C.A, (1990), Measuring Person-Job Fit Using a Profile Comparison Process, Journal of Applied Psychology 75, pp.648-657.

Chatman, J. A. (1991), Matching People and Organizations: Selection and Socialization In Public Accounting .Rms. Administrative Science Quarterly, 36, pp.459-484.

Chatman, J., A. (1989). Improving Interactional Organizational Research: A Model of PersonOrganization Fit. Academy of Management Review, 14, pp.333-349.

Dawes, R.: 1988, Rational Choice In An Uncertain World Harcourt Brace Jovanocich, Orlando, Fl

Downey HK, Hellriegel D, Slocum JW Jr. (1975). Congruence Between Individual Needs Organizational Climate, Job Satisfaction and Performance. Academy of Management Journal, 18, pp.149-155.

Goodman, S.A.; Svyantek, D.J. (1999), "PersonOrganization Fit and Contextual Performance: Do
Shared Values Matter", Journal of Vocational Behavior 55, pp.254-275.

Hair, J., Anderson, R., Tahtam, S., Multivariate data analysis. New York, McMillan, 1987.

Hartline, M.D. and Ferrell, O.C.(1996), The Management of Customer-Contact Service Employees. Journal of Marketing, 60.pp.52-70.

Jose, A. and Thibodeaux, M.S., (1999), Institutionalization of Ethics. The Perspective of Managers, Journal of Business Ethics 22, pp.133143.

Kristof, A.L.(1996). Person-Organization Fit: An Integrative Review of Its Conceptualizations, Measurement, and Implications. Personnel Psychology, 49, p.149

Lakhe, R.R., Mohanty, R.P., (1994). Total quality management: concepts, evolution and acceptability in developing economies. International Journal of Quality \& Reliability Management 11 (9), 9-33.

Lewis, D., (1996). The organizational culture saga from OD to TQM: A critical review of the literature. Part 2-applications. Leadership \& Organization Development Journal 17 (2), 9-16.

Malloy, D.C. ; Agarwal, J., (2003), Factors Influencing Ethical Climate In A Nonprofit Organization: An Empirical Investigation, International Journal of Nonprofit And Voluntary Sector Marketing. London: Vol.8, Iss.3;Aug. pp.224250.

Maull, R., Brown, P., Cliffe, R., (2001).

Organizational culture and quality improvement. International Journal of Operations \& Production Management 21 (3), 302-326.

Meglino, B.M., Ravlin, E.C., \& Adkins, C.L. (1989). A Work Values Approach To Corporate Culture: A Test of The Values Congruence Process and Its Relationship To Individual Outcomes. Journal of Applied Psychology, 74 (3), pp.424-432.

Morris, J. H. and D. J. Sherman: (1981), Generalizability of Organizational Commitment Model, Academy of Management Journal 24, pp.512526.

Netemeyer, R.G. ; Boles, J.S; Mckee, D.O and. Mcmurrian, R (1997), An Investigation Into The 
Antecedents of Organizational Citizenship Behaviors In a Personal Selling Context. J. Mark. 61, pp. 85-98.

Ngowi, A.B., (2000). Impact of culture on the application of TQM in the construction industry in Botswana. International Journal of Quality \& Reliability Management 17 (4/5), 442-452.

Nunnally, J., (1967). Psychometric theory. McGraw Hill, New York.

O'Reilly, C.A; Chatman, J., and Caldwell, D.F, (1991), People and Organizational Culture: A Profile Comparison Approach To Assessing PersonOrganization Fit, Academy of Management Journal 34, pp.487-516.

O'Reilly CA, Chatman J, Caldwell DF (1991). People and organizational culture: A profile comparison approach to assessing person-organization fit. Academy of Management Journal, 34, 487-516.

Ostroff.,C., (1993). Relationships Between PersonEnvironment Congruence and Organizational Effectiveness. Group and Organization Management, 18(1), pp.103-122.

Page, R., Curry, A., (2000). TQM-a holistic view. The International Bi-Monthly for Total Quality Management: The TQM Magazine 12 (1), 11-17.

Porter, L.W.; R.M. Steers, R. T. Mowday and P.V. Boulian: (1974), Organizational Commitment, Job Satisfaction, and Turnover Among Psychiatric Technicians, Journal of Applied Psychology 59, pp.265-288.

Pritchard R.D, Karasick B.W. (1973). The Effects of Organizational Climate on Managerial Job Performance and Job Satisfaction. Organizational Behavior and Human Performance, 9. pp.126-146.

Randi, L. Sims, (1998), When Formal Ethics Policies Differ From Informal Expectations: A Test of Managers Attitudes, Leadership \& Organization Development Journal, Vol:19, Issue:7, pp.386-392.

Reeves, C., Bednar, D., (1994). Defining quality: Alternatives and implications. Academy of Management Review 19 (3), 419-445.

Rothstein, M. and D. Jackson: (1980), DecisionMaking In The Employment Interview: An Experimental Approach, Journal of Applied Psychology 65, pp.271-283
Saks, A. M., \& Ashforth, B. E. (1997). A Longitudinal Investigation If The Relationships Between Job Information Sources, Applicant Perceptions of .T, and Work Outcomes. Personnel Psychology, 50, pp.395-426.

Sandholm, L., (1999). Trendy versus effective quality strategies. The International Bi-Monthly for Total Quality Management: The TQM Magazine 11 (6), 437-444.

Schneider, Benjamin, and J. Rentsch. (1988).

Managing Climates and Cultures: A Futures

Perspective. In Futures of Organizations. Ed. J. Hage.

Lexington, MA: Lexington Books.

Schwepker, C.H., Jr.: (2001), Ethical Climate's Relationship To Job Satisfaction, Organizational Commitment, and Turnover Intention In The Sales force, Journal of Business Research 54, pp.39-52.

Schwepker, Charles H., Jr., O.C. Ferrell, and Thomas N. Ingram, (1997), The Influence of Ethical Climate and Ethical Conflict on Role Stress In The Sales Force, Journal of The Academy of Marketing Science, 25 (Spring), pp. 99-108.

Sims, R. L. and K. G. Kroeck: (1994), The Influence of Ethical Fit on Employee Satisfaction, Commitment and Turnover, Journal of Business Ethics 13, pp.939-947

Sims, R.L. and Keon, T.L., (1997), Ethical Work Climate as a Factor in the Development of PersonOrganization Fit, Journal of Business Ethics 16, pp.1095-1105

Snyder, M., E. Berscheid and A. Matwyck: (1988) Orientation toward Personnel Selection: Differential Reliance Appearance and Personality' Journal of Personality and Social Psychology 54, pp.972-979.

Steers, R.: (1977), Antecedents and Outcomes of Organizational Commitment, Administrative Science Quarterly 22, pp.46-56.

Trevino, L. K., K. D. Butterfield and D. L. McCabe: (1998), The Ethical Context In Organizations: Influence on Employee Attitudes and Behaviors', Business Ethics Quarterly 8, pp.447-476.

Tziner A. (1987). Congruency Issue Retested Using Fineman's Achievement Climate Notion. Journal of Social Behavior and Personality, 2, pp.63-78. 
Upchurch, Randall S. and Sheila K. Ruhland, (1996), The Organizational Bases of Ethical Work Climates In Lodging Operations as Perceived By General Managers, Journal of Business Ethics, 15 (October), pp.1083-1093

Valentine, S.; Godkin, L. and Lucero, M., (2002), Ethical Context, Organizational Commitment and Person-Organization Fit, Journal of Business Ethics 41, pp.349-360.

Vancouver J. B, Schmitt Nw. (1991). An Exploratory Examination of Person-Organization Fit:

Organizational Goal Congruence, Personnel Psychology, 44, pp.333-352.

Vancouver J.B., Millsap Re, Peters Pa. (1994). Multilevel Analysis of Organizational Goal Congruence. Journal of Applied Psychology, 79, pp.666-679.

Vianen, E. M. Van, (2000), "Person-organization fit: The match between newcomers' and recruiters' preferences for organizational cultures", Personnel Psychology. Durham: Spring. Vol. 53, Iss. 1; pg. 113-150.

Victor, Bart And John B. Cullen. (1988). The Organizational Bases of Ethical Work Climates. Administrative Science Quarterly 33 (March): pp.101-25.

Vidaver-Cohen, D., (1998), Moral Climate In Business Firms: A Conceptual Framework For Analysis and Change, Journal of Business Ethics 17, pp.1211-1226.

Williams, L. J. and S.E. Anderson: (1991), Job Satisfaction and Organizational Commitment as Predictors of Organizational Citizenship and In-Role Behaviors, Journal of Management 17, pp.601-617.

Wimbush, James C. and Jon M. Shepard. (1994). "Toward Understanding of Ethical Climate: Its Relationship To Ethical Behavior and Supervisory Influence. Journal of Business Ethics 13 (August): pp.637-47.

Zehir, C.; Elçi, M.; Savi, F.Z., (2003), Ethical Climate's Relationship To Job Satisfaction, Organizational Commitment and Turnover Intention, HUEM, 1st. International Business and Professional Ethics Congress of Turkey. , Sept.17-19. pp. 615628. 